\title{
Article
}

\section{Historic Rights in the South China Sea}

\author{
Ye, Qiang
}

Available at https://clok.uclan.ac.uk/31174/

Ye, Qiang (2019) Historic Rights in the South China Sea. The Korean Journal of International and Comparative Law, 7 (2). pp. 208-225. ISSN 2213-4476

It is advisable to refer to the publisher's version if you intend to cite from the work.

http://dx.doi.org/10.1163/22134484-12340125

For more information about UCLan's research in this area go to

http://www.uclan.ac.uk/researchgroups/ and search for <name of research Group>.

For information about Research generally at UCLan please go to http://www.uclan.ac.uk/research/

All outputs in CLoK are protected by Intellectual Property Rights law, including Copyright law. Copyright, IPR and Moral Rights for the works on this site are retained by the individual authors and/or other copyright owners. Terms and conditions for use of this material are defined in the policies page.

\section{CLoK}

Central Lancashire online Knowledge www.clok.uclan.ac.uk

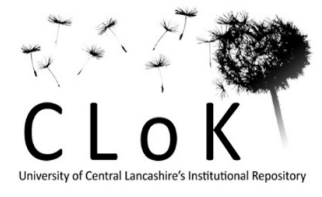




\section{Korean Journal of International and Comparative Law Historic Rights in the South China Sea: A Chinese Perspective --Manuscript Draft--}

\begin{tabular}{|l|l|}
\hline Manuscript Number: & KJIC-1131 \\
\hline Full Title: & Historic Rights in the South China Sea: A Chinese Perspective \\
\hline Short Title: & Historic Rights in the South China Sea: Chinese Perspective \\
\hline Article Type: & Full Length Article \\
\hline Corresponding Author: & Qiang Ye \\
\hline Corresponding Author's Institution: & CHINA \\
\hline First Author: & Qiang Ye \\
\hline Order of Authors: & Qiang Ye \\
\hline Manuscript Region of Origin: & CHINA \\
\hline Abstract: & Abstract to follow \\
\hline Keywords: & Historic Rights, South China Sea, Chinese Perspective, law of the sea, international \\
\hline Funding Information: & law \\
\hline
\end{tabular}


Historic Rights in the South China Sea: A Chinese Perspective

Qiang Ye, Research Associate, National Institute for South China Sea Studies, China \& PhD Candidate, Lancashire Law School, University of Central Lancashire, UK (email: QYe4@uclan.ac.uk) 


\section{Historic Rights in the South China Sea: A Chinese Perspective}

\section{INTRODUCTION}

'Historic rights' has been a complicated issue in the law of the sea both conceptually and practically. China's sovereign and maritime claims in the South China Sea, which are marked through the 'U-shaped line' or 'dotted-line' or 'nine-dash line,' touch upon the historic rights and have been regarded as one of the most controversial issues among East Asian maritime disputes so far. Recent years, the South China Sea Arbitration case between the Philippines and China raised important issues regarding the contemporary relevance and validity of historic claims, and the relationship between the Law of the Sea Convention (hereinafter the 'LOS Convention') and historic rights. This article would not examine a comprehensive theory of historic rights, rather, it will just give case by case studies and will compare certain international practice with China's claims from the perspective of literal interpretation, and then examine the possible content and nature of historic-related claims in the South China Sea by China based on its existing positions.

In the first part, it will give a relevant background of China's historic-related claims and relevant considerations of these claims on the international law; in the second part, it will identify and discuss in depth the most recent development of China's historic rights claims and practice, from which the geographic scope and nature of those rights may be presumed; in the third part, it will examine the potential legal consequences of these claims for the dispute settlement procedures under the LOS Convention; and finally, a conclusion will be given.

\section{EVOLUTION OF CHINA'S CLAIMS TO THE HISTORIC-RELATED RIGHTS IN THE SOUTH CHINA SEA AND THE CONDIDERATIONS OF THESE CLAIMS UNDER THE INTERNATIONAL LAW}

So far, China has not yet explicitly declared the nature, content or geographic scope of historic rights it claims in the South China Sea region. In addition, with a number of legal terms used in the historical context, such as 'right,' 'title,' and 'consolidation,' it 
is even more complicated when one tries to examine China's claim on the historic rights. Yet it is necessary to look through China's practice relating to historical context in the past decades.

\section{Historic Bays and Historic Waters}

China first expressed its view on historic waters in 1957, when it supported the Soviet Union claim to Peter the Great Bay. ${ }^{1}$ In 1958, China issued the Declaration of the Government of the People's Republic of China on China's Territorial Sea (hereinafter the "1958 Declaration of Territorial Sea"), in which the Bohai Bay was enclosed within the baseline and thus was deemed as Chinese inland waters. ${ }^{2}$

The rules related to historic bays can be seen as well-established customary international law. In the North Atlantic Coast Fisheries Case (Great Britain v. United States), Dr. Luis M. Drago put forward the concept of historic bays in the Dissent that: "[I]t may be safely asserted that a certain class of bays, which might be properly called the historical bays such as Chesapeake Bay and Delaware Bay in North America and the great estuary of the River Plate in South America, form a class distinct and apart and undoubtedly belong to the littoral country, whatever be their depth of penetration and the width of their mouths, when such country has asserted its sovereignty over them, and particular circumstances such as geographical configuration, immemorial usage and above all, the requirements of self-defense, justify such a pretension."”3

Professor James L. Brierly also pointed out in the 1940's that "[ $t]$ here are certain bays, sometimes called 'historic bays,' much larger than this (refers to the distance between the low-water marks of the natural entrance points of a bay exceeds 24 nautical miles, noted by the author), which are certainly inland waters."4

Thus in 1959, an official pamphlet was published in China in order to explain

\footnotetext{
1 Zou Keyuan, "Historic Rights in International Law and in China's Practice," 32 Ocean Development and International Law (2001), p. 156.

2 Declaration of the Government of the People's Republic of China on China's Territorial Sea, Sept. 4, 1958, para. 2.

3 North Atlantic Coast Fisheries Case (Great Britain v. United States), in the Reports of International Arbitral Awards (Volume XI), p. 206.

${ }^{4}$ Andrew Clapham, Brierly's Law of Nations: An Introduction to the Role of International Law in International Relations (7 ${ }^{\text {th }}$ Edition), Oxford University Press, 2012, p. 189.
} 
China's 1958 Declaration on the Territorial Sea, this pamphlet gave a further detailed explanation of China's own historic claims. It says that "[a]lthough the natural entrance of some bays or gulfs exceeds 24 nautical miles, if the bays or gulfs are important to the national defense and economy of the coastal states and for a long period the coastal states have repeatedly exercised jurisdiction over the bays or gulfs, they may be regarded as historical bays or gulfs. Regardless of whether or not the mouths of these bays or gulfs exceed 24 nautical miles, they may also be considered as internal bays or gulfs of the coastal states." 5 Obviously, this position was consistent with the international practice at that time.

Besides, China declared in the 1958 Declaration of Territorial Sea that the 'Qiongzhou Straits' was China's inland waters based on historical considerations. The Qiongzhou Strait is located in the South China Sea area. In China's view, the Qiongzhou Strait has an extremely important meaning for China's economy and national defense:

"Historically, it has always been subject to our sovereign jurisdiction and has constituted an inalienable, composite part of our country. Since liberation our country has always administered it as an internal strait. The present Declaration on the Territorial Sea issued by our government is merely to reaffirm once more a historical fact."

This position should also be consistent with the international practice. In the Anglo-Norwegian Fisheries Case (United Kingdom v. Norway), the ICJ defined the 'historic waters' as those "are usually meant waters which are treated as internal waters but which would not have that character were it not for the existence of an historic title." Thus the ICJ found and concluded that:

"Norway can justify the claim that these waters are territorial or internal on the ground that she has exercised the necessary jurisdiction over them for a long period without opposition from other States, a kind of possessio longi temporis, with the

\footnotetext{
5 Zou Keyuan, "Historic Rights in International Law and in China's Practice," 32 Ocean Development and International Law (2001), p. 156.

6 Ibid, p.157.

7 Anglo-Norwegian Fisheries Case (United Kingdom v. Norway), Judgment, 1951 I.C.J. Reports, p. 130.
} 
result that her jurisdiction over these waters must now be recognized although it constitutes a derogation from the rules in force. Norwegian sovereignty over these waters would constitute an exception, historic titles justifying situations which would otherwise be in conflict with international law." 8

During that period, the organs of the United Nations also studied the concepts of historic waters and historic bays. The International Law Commission (ILC) discussed the concept of historic waters in the 1950s, and in 1962 the UN Secretariat, upon the request of the ILC, produced a study on the juridical regime of historic waters, including historic bays. The study examined the elements of title to historic waters, the issue of the burden of proof, the legal status of waters regarded as historic waters, and the settlement of disputes. ${ }^{9}$ The regimes of historic bays and historic waters, therefore, should be regarded as well-established rules of customary international law before the UNCLOS III.

\section{Historic Rights}

The UNCLOS III, however, marked a turning point for the application of historic-related rights. During the UNCLOS III, 'historic waters' was listed as a subitem under Item 2 'territorial sea', which was allocated to the Second Committee. In relevant debate, several formal proposals were made by countries including the Philippines and Indonesia. But unfortunately, no further discussion of historic waters took place in the formal meetings of the Second Committee. ${ }^{10}$ Besides, UNCLOS III did not discuss the issue of 'historic rights.' Thus China did not express its position on these terms in public during the UNCLOS III.

In anticipation of the ratification of the LOS Convention, China promulgated its Law on the Territorial Sea and the Contiguous Zone (hereinafter the "1992 Law on the Territorial Sea") on February 25, 1992. The 1992 Law on the Territorial Sea does not mention any 'historic rights.'

\footnotetext{
8 Ibid.

9 Zou Keyuan, "Historic Rights in International Law and in China's Practice," 32 Ocean Development and International Law (2001), p. 151.

10 Shabtai Rosenne, "Historic Waters in the Third United Nations Conference on the Law of the Sea", in T.D. Gill and W.P. Heere, eds., Reflections on Principles and Practice of International Law (The Hague: Martinus Nijhoff, 2000), pp. 497-511, 501-504.
} 
However, on June 26, 1998, China promulgated its Law on the Exclusive Economic Zone and Continental Shelf (hereinafter the "1998 Law on EEZ and Continental Shelf'), in which the Article 14 has been seen as the most widely-known provision for China to claim historic rights. In this Article, China declared that:

"The provisions of this Act shall not affect the historical rights of the People's Republic of China."11

Although this provision remains unclear that where can China enjoy its historic rights and what's the nature of such rights, we may presume that the historic rights claimed by China are different from the historic bays and historic waters claimed in the 1958 Declaration on the Territorial Sea, and are not situated within the scope of territorial sea. Rather, the historic rights may be claimed not limited by the scope of EEZ or continental shelf determined by the related rules of 1998 Law on EEZ and Continental Shelf.

In 2009, China presented a Note Verbale to the UN to protest other coastal States' joint submissions to the CLCS. In this Note Verbale, China attached the Ushaped line map and pointed out that "China has indisputable sovereignty over the islands in the South China Sea and the adjacent waters, enjoys sovereign rights and jurisdiction over the relevant waters as well as the seabed and subsoil thereof." But China did not mention the term of historic rights in this Note Verbale, thus we cannot assume those mentioned rights refer to historic rights. It is noteworthy that the second paragraph in this Note Verbale declares that " $[\mathrm{t}]$ he above position is consistently held by the Chinese Government, and is widely known by the international community." Given that the U-shaped line map is attached in the Note Verbale, it seems that the 'widely known' position refers to the U-shaped line claim.

The South China Sea Arbitration between the Philippines and China raised important issues regarding the contemporary relevance and validity of historic claims, and the relationship between the LOS Convention and historic rights. These issues

\footnotetext{
11 Article 14, Exclusive Economic Zone and Continental Shelf Act (Adopted the third session of the Standing Committee of the Ninth National People's Congress, 26 June 1998). The UN Website, available at: http://www.un.org/depts/los/LEGISLATIONANDTREATIES/PDFFILES/chn_1998_eez_act.pdf 
were triggered by the Philippine Submissions 1 and 2 in its Memorial, which reads:

"1. China's maritime entitlements in the South China Sea, like those of the Philippines, may not extend beyond those permitted by the United Nations Convention on the Law of the Sea;

2. China's claims to sovereign rights and jurisdiction, and to 'historic rights,' with respect to the maritime areas of the South China Sea encompassed by the socalled 'nine-dash line' are contrary to the Convention and without lawful effect to the extent that they exceed the geographic and substantive limits of China's maritime entitlements under UNCLOS." 12

The Arbitral Tribunal issued its final award on July 12, 2016. To respond the award, China issued the Statement on China's Territorial Sovereignty and Maritime Rights and Interests in the South China Sea (hereinafter the "2016 Statement") on the same day. In this Statement, China clearly affirmed that it has enjoyed historic rights in the South China Sea:

"China has territorial sovereignty and maritime rights and interests in the South China Sea, including, inter alia:

i. China has sovereignty over Nanhai Zhudao, consisting of Dongsha Qundao, Xisha Qundao, Zhongsha Qundao and Nansha Qundao;

ii. China has internal waters, territorial sea and contiguous zone, based on Nanhai Zhudao;

iii. China has exclusive economic zone and continental shelf, based on Nanhai Zhudao;

iv. China has historic rights in the South China Sea."13

To compare the 2016 Statement with the 2009 Note Verbales, it is easily to be found that the two are largely consistent. The "sovereignty over the islands in the South China Sea and the adjacent waters" mentioned in the 2009 Note Verbale, refers

\footnotetext{
12 The Philippines' Memorial - Volume I, The South China Sea Arbitration (The Republic of Philippines v. The People's Republic of China), p. 271. Available online: https://files.pcacpa.org/pcadocs/Memorial\%20of\%20the\%20Philippines\%20Volume\%20I.pdf 13 Statement of the Government of the People's Republic of China on China's Territorial Sovereignty and Maritime Rights and Interests in the South China Sea (12 July 2016)
} 
to the statement points $\mathrm{i}$ and ii; the "sovereign rights and jurisdiction over the relevant waters as well as the seabed and subsoil thereof" refers to the statement points iii and iv.

In conclusion, the above legal documents -- the Article 14 of the 1998 Law on EEZ and Continental Shelf, the 2009 Note Verbale with the U-shaped line map, and the 2016 Statement - outlined China's claim on 'historic rights' in the South China Sea. Further to identify the concrete rights China claimed in the South China Sea, the U-shaped line cannot be ignored.

\section{THE U-SHAPED LINE AND CHINA'S EVOLVING POSITIONS ON THE GEOGRAPHIC SCOPE AND CONTENT OF HISTORIC RIGHTS IN THE SOUTH CHINA SEA}

\section{The Nature and Content of Historic Rights China Enjoys within the U-} shaped Line

The Chinese term for the 'U-shaped line' might best be translated as 'traditional sea boundary line,' which also refers to historic considerations. The U-shaped line originally came into being in 1914 and later gradually expanded in a southerly direction. It was officially confirmed in 1947 after World War II. Since then the line has remained unchanged on all the Chinese maps published either in the mainland or in Taiwan. For a long time, China has kept silent and offered no express statement for this line.

It is noteworthy that in the 2016 Statement, the term 'U-shaped line' is only mentioned once at the beginning of the Statement:

"To strengthen the administration over Nanhai Zhudao, the Chinese government in 1947 reviewed and updated the geographical names of Nanhai Zhudao, compiled Nan Hai Zhu Dao Di Li Zhi Lüe (A Brief Account of the Geography of the South China Sea Islands), and drew Nan Hai Zhu Dao Wei Zhi Tu (Location Map of the South China Sea Islands) on which the dotted line is marked. This map was officially published and made known to the world by the Chinese government in February 
Thus some scholars may suppose that the U-shaped line claim has been dropped or de-emphasized by the Chinese government, because "the Chinese leadership may have realized that the Nine Dash Line has become too much of a diplomatic liability. The Nine-Dash Line is completely sui generis and no other state has made a historic maritime claim anything like it. For this reason, the Nine-Dash Line makes China an easy target for foreign criticism in a way that straight baselines around island groups probably will not."15

However, according to China's practice, this is not the case. While the geographical scope of the lines has been almost unchanged over the years, the content of the rights embraced by them may have evolved, with Chinese practice being informed by developments in the law of the sea, including its own ratification of the LOS Convention. ${ }^{16}$

Presently, the authoritative interpretation on the implications of the U-shaped line, from Chinese perspective, may include three factors:

"The reasonable proposition is that the nine-dash line, after sixty years of evolution, has become 1) synonymous with a claim of sovereignty over the island groups that always belonged to China; 2) an additional Chinese claim of historical rights of fishing, navigation, and other marine activities (including the exploration and exploitation of resources, mineral or otherwise) on the islands and in the adjacent waters; 3) lines may also have a residual function as potential maritime delimitation boundaries." 17

The Chinese government 2016 Statement has obviously concretised the rights which may be included in the U-shaped line claim, rather than de-emphasized this line.

\footnotetext{
14 Ibid, para. 1.

15 Julian Ku and Chris Mirasola, "The South China Sea and China's 'Four Sha' Claim: New Legal Theory, Same Bad Argument," Lawfare, available at: https://www.lawfareblog.com/south-china-sea-and-chinas-four-sha-claim-newlegal-theory-same-bad-argument

16 Zhiguo Gao and Bing Bing Jia, "The Nine-Dash Line in the South China Sea: History, Status, and Implications," American Journal of International Law, Volume 107, Issue 1, p. 118.

17 Ibid, p. 108.
} 
Another question arises in the context of the nature of historic rights in the South China Sea is the relations between these rights and those under the LOS Convention.

There are no provisions in the LOS Convention which explicitly refer to historic rights. The reason why the Convention is silent on this issue seems that "there was no discussion on the general question of historic rights during UNCLOS III."18 Instead, there are references to 'historic bays' and 'historic title' in Article 10(6), Article 15, and Article 298(1)(a). In general international law, 'historic rights,' 'historic waters,' and 'historic titles' are closely related terms. ${ }^{19}$ As indicated by international practice, rules of historic rights have been evolving constantly and have not given rise to a uniform regime. The ICJ points out that "[general international law] does not provide for a single 'régime' for 'historic waters' or 'historic bays', but only for a particular régime for each of the concrete, recognized cases of 'historic waters' or 'historic bays "'. ${ }^{20}$

In China's view, the above issues, as well as those mentioned in the $L O S$ Convention without detailed regulations, are "matters not regulated by this Convention", and shall continue to be governed by general international law, pursuant to the Preamble of the Convention. ${ }^{21}$ This position is well supported by the jurisprudence of the ICJ. As found by the ICJ, "[n]or does the draft convention of the Third Conference on the Law of the Sea contain any detailed provisions on the 'régime' of historic waters: there is neither a definition of the concept nor an elaboration of the judicial régime of 'historic waters' or 'historic bays'. There are, however, references to 'historic bays' or 'historic titles' or historic reasons in a way amounting to a reservation to the rules set forth therein. It seems clear that the matter continues to be governed by general international law ...", "the notion of historic rights or waters ... are governed by distinct legal regimes in customary international law", and "[h]istoric titles must enjoy respect and be preserved as they have always

\footnotetext{
18 Ma Xinmin, "Merits Award Relating to Historic Rights in the South China Sea Arbitration: An Appraisal", Asian Journal of International Law, Vol. 8, Issue 1 (January 2018), pp. 12-23. 
been by long usage". ${ }^{22}$

During UNCLOS III, it was recognized by some states that the establishment of coastal states' exclusive rights in the EEZ and continental shelf is bound to conflict with historic rights of other states. ${ }^{23}$ During the preliminary discussions, it was proposed by the former Yugoslavia, Sierra Leone, and Mexico that the potential conflict should be addressed by regional regimes and bilateral treaties. ${ }^{24}$ The relationship between exclusive rights in the EEZ and continental shelf and historic rights was not discussed in depth and no agreement was reached. With respect to the continental shelf, although the ICJ held in the Tunisia/Libya case that the regime of the continental shelf is based on the existence of rights "ipso facto and ab initio", ${ }^{25}$ it did not say historic rights cannot play a role in the delimitation of the continental shelf. ${ }^{26}$ One of the judges explicitly argued that a legal concept such as the the continental shelf "cannot by itself have the effect of abolishing or denying acquired or existing rights". ${ }^{27}$ As the rules has been well established in general international law, 'historic rights' were not superseded by the regimes of the EEZ and continental shelf.

\section{The Geographical Scope where China Enjoys the Historic Rights within}

\section{the U-shaped Line}

With the ratification of the LOS Convention, the content of the rights enjoyed by China within the U-shaped line may have evolved. And consequently, the geographical scope where China enjoys the historic rights may also have changed.

As mentioned above, China does not claim historic rights in its territorial seas. Although the territorial sea exists ipso facto and ab initio, and the lack of publicity and non-deposition of charts or lists of geographical coordinates do not make any difference in this matter, ${ }^{28}$ the geographic scope of territorial sea both in Xisha

\footnotetext{
22 Continental Shelf (Tunisia/Libyan Arab Jamahiriya), Judgment, 1982, I.C.J. Reports, p. 18, para. 100.

23 The Third United Nations Conference on the Law of the Sea, A/CONF.19/C.1/SR.2, pp. 40-41, paras. 12-22.

24 The Third United Nations Conference on the Law of the Sea, A/ CONF.19/C.1/SR.8, p. 70, para. 41; The Third United Nations Conference on the Law of the Sea, A/ CONF.19/C.1/SR.15, p. 99, para. 29; The Third United Nations Conference on the Law of the Sea, A/ CONF.19/C.1/SR.24, p. 113, para. 7.

${ }_{25}$ Continental Shelf (Tunisia/Libyan Arab Jamahiriya), Judgment, 1982, I.C.J. Reports, p. 18, para. 100.

${ }^{26}$ Sophia Kopela, "Historic Titles and Historic Rights in the Law of the Sea in the Light of the South China Sea Arbitration," 48 Ocean Development and International Law (2017), p. 10.

27 Continental Shelf (Tunisia/Libyan Arab Jamahiriya), Judgment, 1982, I.C.J. Reports, Separate Opinion by Judge Jimenez de Arechaga, para. 82.

28 Xinjun Zhang, "The Latest Developments of the US Freedom of Navigation Programs in the South China Sea:
} 
Deregulation or Re-balance," 9 J. E. Asia \& Int'| L. (2016) p.178.

${ }_{29}$ Award, PCA Case No. 2013-19, paras. 575-576, available online: https://www.pcacases.com/web/sendAttach/2086

30 See: UN Convention on the Law of the Sea, available online: http://www.un.org/depts/los/convention_agreements/texts/unclos/unclos_e.pdf

31 See: Law of the People's Republic of China on the Territorial Sea and the Contiguous Zone, available online: http://www.lawinfochina.com/display.aspx?lib=law\&id=670

32 Award, PCA Case No. 2013-19, para. 575, available online: https://www.pcacases.com/web/sendAttach/2086 
Article 46, it turned out that a number of States with dependent archipelagos, such as Ecuador with the Galapagos, sought to have them included. Competing versions appears in the texts that were considered during the 1974 and 1975 sessions of the Third Conference. But that proposal did not achieve consensus, and was dropped in the version considered at the fourth session in 1976, the RSNT, and did not reappear subsequently.

Therefore, the fact that neither Article 5 on the normal baseline nor Article 7 on straight baselines explicitly preclude their use to enclose dependent archipelagos, makes it is possible that the last preambular paragraph of the LOS Convention applies. That paragraph states that "matters not regulated by the [LOS] Convention continue to be regulated by the rules and principles of general international law." 33

It is necessary to examine the Anglo-Norwegian Fisheries case carefully and identify the factors which regarded by the ICJ as to be fundamental for justifying the establishment of straight baseline. In this case, the ICJ identified "certain basic considerations inherent in the nature of the territorial sea":

"Another fundamental consideration, of particular importance in this case, is the more or less close relationship existing between certain sea areas and the land formations which divide or surround them...

Finally, there is one consideration not to be overlooked, the scope of which extends beyond purely geographical factors: that of certain economic interest peculiar to a region, the reality and importance of which are clearly evidenced by a long usage." 34

Obviously, the considerations on the adoption of straight baseline include not only the purely geographical factors, but also the social historical factors as well as the economic factors. This is the case for the reason why China established straight baseline to enclose the Xisha Islands. ${ }^{35}$

\footnotetext{
33 See: UN Convention on the Law of the Sea, available online: http://www.un.org/depts/los/convention_agreements/texts/unclos/unclos_e.pdf

34 Fisheries case, Judgment of December $18^{\text {th }}$, 1951: ICJ Reports 1951, p. 133, available online: http://www.icjcij.org/files/case-related/5/005-19511218-JUD-01-00-EN.pdf

35 International Law in China: Cases and Practice (in Chinese, Duan Jielong eds.) China Law Press 2011, pp. 84-85.
} 
Furthermore, there are more than 10 dependent archipelagos worldwide that have been enclosed with straight baselines: the Faroes (Denmark), Svalbard (Norway), the Canary Islands (Spain), the Azores (Portugal), Kerguelen Islands (France), Galapagos (Ecuador), the Bijagos Archipelago (Guinea-Bissau), the Arctic archipelago (Canada), Co Co and Preparis Islands (Myanmar), etc.

Even though this state practice over the decades cannot be deemed as a rule of customary international law since there are a few oppositions which prevented the development of a uniform and widely accepted practice, it is unreasonable to conclude that the use of straight baselines to enclose dependent archipelagos is contrary to the LOS Convention or customary international law.

The situation in Nansha is more complicated. There are sharp differences on legal status of certain maritime features, and consequently, on maritime entitlement for each feature as well as the Nansha Islands as a whole.

China has long been reiterated the position that it enjoys the sovereignty, sovereign rights and maritime jurisdiction over the Nansha Islands in its entirety, rather than the single island or reef or low tide elevation. The 1958 Declaration of Territorial Sea indicated that "[ $[\mathrm{t}] \mathrm{he}$ breadth of the territorial sea of the People's Republic of China shall be twelve nautical miles. This provision applies to all territories of the People's Republic of China including the Chinese mainland and its coastal islands, as well as Taiwan and its surrounding islands, the Penghu Islands, the Dongsha Islands, the Xisha Islands, the Zhongsha Islands, the Nansha Islands and all other islands belonging to China which are separated from the mainland and its coastal islands by the high seas." 36

In Note Verbale No. CML/8/2011 of 14 April 2011 addressed to SecretaryGeneral of the UN, the Permanent Mission of China to the UN stated that "under the relevant provisions of the 1982 [LOS Convention], as well as the Law of the People's Republic of China on the Territorial Sea and the Contiguous Zone (1992) and the Law on the Exclusive Economic Zone and the Continental Shelf of the People's Republic

\footnotetext{
36 Declaration of the Government of the People's Republic of China on China's Territorial Sea, September 4, 1958, available online: https://www.chinausfocus.com/upload/file/2014/Annex1-4.pdf
} 


\section{LEGAL CONSEQUENCES OF CHINA'S CLAIMS FOR THE DISPUTE SETTLEMENT PROCEDURES UNDER THE LOS CONVENTION}

First, China believes that any dispute involving historic rights should be excluded from the compulsory dispute settlement procedures under the LOS Convention. This argument is based on the fact that historic rights originated from customary international law rather than the LOS Convention.

The optional exceptions allowed by Article 298 include "disputes involving historic bays or titles," which reads:

\footnotetext{
37 Position Paper of the Government of the People's Republic of China on the Matter of Jurisdiction in the South China Sea Arbitration Initiated by the Republic of the Philippines (2014/12/7), para. 21, available online: http://www.fmprc.gov.cn/mfa_eng/zxxx_662805/t1217147.shtml

38 Statement of the Government of the People's Republic of China on China's Territorial Sovereignty and Maritime Rights and Interests in the South China Sea (2016/07/12), available online: http://www.fmprc.gov.cn/nanhai/eng/snhwtlcwj_1/t1379493.htm
} 
"1. When signing, ratifying or acceding to this Convention or at any time thereafter, a State may, without prejudice to the obligations arising under section 1 , declare in writing that it does not accept anyone or more of the procedures provided for in section 2 with respect to one or more of the following categories of disputes:

(a) (i) disputes concerning the interpretation or application of Articles 15, 74 and 83 relating to sea boundary delimitations, or those involving historic bays or titles..." ${ }^{\prime 39}$

The South China Sea Arbitration touches upon this exception by Philippines' second Submission. In the Position Paper of the Government of the People's Republic of China on the Matter of Jurisdiction in the South China Sea Arbitration Initiated by the Republic of the Philippines (hereinafter the "2014 Position Paper"), China did not argue an exception based on its historic rights.

However, China appears to take the view that Article 298 should apply to discussions of "historic rights", as evidenced in a short note posted on the website of the Chinese Mission to the European Union. This note says:

"The negotiating history and official languages of the UNCLOS, as well as the wording of its Article 298 show that 'historic titles' under Article 298 do not refer to sovereignty only. Consequently, the dispute involving China's historic rights is covered by Article 298, and should be excluded from compulsory arbitration." 40

But the Tribunal rejected China's position. It differentiated the terms "historic rights", "historic waters," "historic bays," and "historic titles." And concluded that "China has invoked its 'historic rights' in the South China Sea, rather than 'historic title', as China had not at any point claimed 'sovereignty over the entirety of the South China Sea.' " Based on this, the tribunal concluded that it had jurisdiction to consider the Philippines' first and second Submissions. However, this differentiation is meaningless in this case. The Tribunal ignored a critical issue that the relationship between "disputes involving historic bays or titles" and the "interpretation or application of the Convention.” Although Article 298(1)(a)(i) does not qualify

\footnotetext{
39 Article 298 Optional exceptions to applicability of Section 2

${ }^{40}$ A Preliminary Report of the Facts Related to the Issue of Historic Rights Involved in the South China Sea Arbitration and the Applicability of Laws in This Case, 30 June 2016
} 
"disputes involving historic bays or titles" by reference to the "interpretation or application of the Convention," Articles 286 to 288 have implied this qualification. Thus, all disputes outside the scope of "interpretation or application of the Convention," including those involving historic rights, are excluded from the compulsory procedures.

Even the Tribunal accepted that "China's assertions indicate a claim to rights arising independently of the Convention." ${ }^{\circ 1}$ The reason why Article 298 specifically mentions "historic bays" and "historic titles," seems that these are the terms used elsewhere in the Convention (such as Article 10(6) which refers to "historic bays" and Article 15 refers to "historic title").

Thus, disputes involving "historic rights" should be regulated by customary international law rather than the Convention.

Second, China's claims to historic rights obviously refers to maritime delimitation, which is excluded from compulsory dispute settlement procedures by Article 298(1)(a)(i).

On July 13, 2016, China issued a white paper called China Adheres to the Position of Settling Through Negotiation the Relevant Disputes Between China and the Philippines in the South China Sea, under the section of "maritime delimitation in the South China Sea", paragraph 127 pointed out that:

"China's positions on maritime delimitation in the South China Sea are further elaborated in the 1998 EEZ and Continental Shelf Law. This Law provides that, "[t]he People's Republic of China shall determine the delimitation of its exclusive economic zone and continental shelf in respect of the overlapping claims by agreement with the states with opposite or adjacent coasts, in accordance with the principle of equitability and on the basis of international law', and that, '[t]he provisions in this law shall not affect the historical rights that the People's Republic of China has been enjoying ever since the days of the past'. ${ }^{\prime 42}$

\footnotetext{
41 Award, SCS Arbitration case, para.207

${ }^{42}$ China Adheres to the Position of Settling Through Negotiation the Relevant Disputes Between China and the Philippines in the South China Sea (13 July 2016)
} 
${ }^{43} M / V$ "Louisa" (Saint Vincent and the Grenadines v. Kingdom of Spain), Judgment, ITLOS Reports 2013, p.31, para. 83.

44 Aegean Sea Continental Shelf Case (Greece v. Turkey), Judgment of 19 December 1978, I.C.J. Reports 1978, p. 36, para. 86.

45 Decision on Australia's Objections to Competence, Conciliation between the Democratic Republic of TimorLeste and the Commonwealth of Australia, PCA Case No. 2016-10, p. 27, para. 97. 


\section{CONCLUSION}

China's historic rights in the South China Sea have been in existence since long ago. The Chinese people have cherished relevant areas of the South China Sea as their home where they live and work, and firmly believe that the islands and reefs and relevant sea areas are within China's domain. The Chinese government in successive periods have also exercised jurisdiction over the maritime features and relevant areas continuously, peacefully and effectively. Although the LOS Convention is silent on the relationship between historic rights and the regimes of EEZ and continental shelf, the Convention exhibits is respect for historic rights in Articles 10, 15, 51, and 298. Since the 1950s, China's positions and practice regarding the historic-related rights should be well consistent with the international practice. Given the complicated situations of the sovereign and maritime disputes in the South China Sea, it is still not clear that where and what concrete rights China would claim within the U-shaped line. Nevertheless, any dispute involving historic rights should be excluded from the compulsory dispute settlement procedures under the LOS Convention. 